\section{DOI: https://doi.org/10.18524/2410-2601.2021.1(35).246717}

\section{УДК 111.852:82.09 Свгенія Буцикіна КОМЕНТАР ДО УКРАЇНСЬКОГО ПЕРЕКЛАДУ} ТВОРУ ЖОРЖА БАТАЯ «ВНУТРІШНІЙ ДОСВІД»

Коментар присвячений проблематичі перекладу украйнською твору «Внутрішній досвід» відомого франиузького інтелектуала ХХ століття Жоржа Батая. В роботі окреслено коротку історію публікачій $i$ розширень «Внутрішнього досвіду», що становить для перекладача певну складність і початкову умову для неповного перекладу твору, щзо не був опублікований в повному обсязі за життя свого автора. Також в тексті здійснено аналіз ключових філософських термінів, переклад яких супроводжувався проблематичністю: зокрема ие такі поняття, як «angoisse» (тривога), «supplice» (муки), «соттипісаtion» (комунікація), «discourse»(дискурс), «еsprit»(дух), «entendement» (розуміння), «intelligence» (розум), «savoir» (знання), «connaissance» (пізнання), «ірse» (не перекладене) та «ірsеité» (самість). Наголошено на антидискурсивності та поетизованості як ключових характеристиках письма Батая, що також сприяло ускладненню такої задачі, як переклад праці «Внутрішнього досвід».

Ключові слова: Батай, дискурс, досвід, комунікачія, муки, самість, тривога.

Переклад будь-якого твору Жоржа Батая, становить виклик для перекладача, як формально, так і змістовно. Це стосується і його праці 1943 року «Внугрішній досвід». Сам текст напрочуд неоднорідний, непослідовний і стилістично строкатий (і свідомо полишений таким), він не вписується повністю ані в літературну стилістику, ані в філософську. Як зазначає дослідник Батая Б. Нойс, «Батай намагається відтворити насильницьку неоднорідність Ніцше у власних працях. Разом із Ніцше він розвиває свій власний стиль письма, запозичений і неповторний водночас» [Noys: 39]. Окремі частини цього твору (тексти «Лабіринт», «Небесна блакить», «Муки» та ін.) були написані Батаєм ще у 20-х і 30-х роках. Він об'єднує та доповнює їх на початку 40-х, під час нацистської окупації Франції, у маленькому містечку Везелей, страждаючи на напади туберкульозу та самотності (Батай відірваний від своїх однодумців, друзів і коханої жінки). Нами перекладене друге видання «Внутрішнього досвіду» 1956 року, доповнене вбудованими у текст ремарками Батая, що вони виділені курсивом. Цей варіант Батай планував доповнити іншими невеликими творами: «Метод медитації» та «Постскриптум 1953». Зрештою український переклад отримав все ще недосконалий текст «Внутрішнього досвіду», але такий, що бодай містить у собі рефлексію автора. Додатково в українському перекладі наявні коментарі і нотатки Батая, взяті упорядниками видавництва Gallimard із його різноманітних чернеток, щоденників і зошитів [Bataille 1973]. Для українського читача відібрана лише частина цих коментарів - ті, що містять змістовні доповнення ключових понять «Внутрішнього досвіду».

Щодо змістовного, концептуального аспекту цієї роботи, метою перекладача було, перш за все, вбудувати український текст Батая у сформовану поняттєву традицію українських перекладів. Хоча варто враховувати особистість Батая, який принципово не вписувався у європейську філософську традицію, у французьку - зокрема.

Це виразно помітно у разі поняття «angoisse», яке можна було б перекласти і як «туга», і як «тривога». В обох наявних англійських перекладах [Boldt 1988; Kendall 2014] використовується аналог «anguish», якому відповідають українські поняття «туга», «мука», «страждання», але жодне 3 яких не є досконалим відповідником ані французького, ані англійського термінів. Ми зупинилися на понятті «тривога», адже саме воно надає можливість вписати Батая в наявну екзистенціалістсько-феноменологічну традицію. Відомо, що Батай був знайомий з творами «Поняття тривоги» («Begrebet Angest») C. К’єркєгора, «Що таке метафізика» М. Гайдегера, а також із творчістю Ж.-П. Сартра, чия робота «Бугтя і ніщо» побачила світ в один рік із «Внутрішнім досвідом» Батая (1943). Ми можемо розуміти «тривогу» К'єркєгора, Гайдегера і Сартра як безоб'єктну (на відміну від страху). Аналогічно, «внутрішній досвід» Батая не має посилання на трансценденцію - ні до знань, ні до Бога. Це досвід порожнечі, ночі, незнання. Як зазначає дослідник Г. Руссо, аналізуючи концепт тривоги в художніх творах Батая, «...смерть Бога не є ознакою безтурботного атеїзму, навпаки, вона виявляє на небі неможливий заповнити вакуум, занурюючи людину в тривогу, розриваючи іiі» [Rousseau 2015]. У «Внутрішньому досвіді» (і в прозі, і в поезії) сам Батай часто використовує метафору мовчазного, порожнього, знебожествленого неба, відсугність відповіді якого стає підгрунтям для розростання тривоги: «по той бік пізнаних можливостей тривога стрімко оселяється у сірому небі, наче чернець у темряві могили».

Окрім цього, використання поняття «angoisse» саме у значенні «тривога» притаманне психоаналітичній традиції. Як зазначено в біографічних нотатках Батая, він проходив курс психоаналізу і був знайомий iз психоаналітичною термінологією [Bataille 1976: 459]. Також варто згадати, що одним із джерел, що мали безпосередній вплив на створення «Внутрішнього досвіду», була робота французького психіатра П. Жане «Від тривоги до екстазу» («De l'angoisse ? l'extase», 1927). У своєму творі Жане 
описує стани однієї релігійної пацієнтки на ім'я Мадлен, що переходили від стадії тривоги (хоча, i «туга», i «мука», i «страждання» як види релігійних переживань тут теж релевантні) до стадії екстазу [Janet 1926: 11-16]. Очевидно, Батай бере за основу стан пацієнтки Жане для метафоричного позначення і подальшого опису внутрішнього досвіду. Він спирається на специфічний психологічний стан релігійного переживання, який Жане аналізував як психіатр, прагнучи посилення антирелігійної наукової настанови, і порівнює його зі станами християнських містиків (Анджела 3 Фоліньйо, Тереза Авільська, св. Іоанн від Хреста): «...життя в християнстві засуджується, але прогресивні люди освячують його; християни обмежили життя до екстазу та гріха (це було позитивне ставлення), а прогрес заперечує екстаз та гріх, та ототожнює життя з проектом, освячує проект (роботу): в світі прогресу життя ніщо інше, як дозволена дитячість, треба лише визнати проект серйозною справою (тривога, яку живлять нещастя, необхідна авторитету, але дух зайнятий проектом)». Натомість, Батай надає цьому стану філософського значення, водночас критикуючи як релігійну, так i філософські настанови Декарта і Гегеля. У передмові до своєї книжки він зазначає: «Дух рухається дивним світом, в якому об'єднані тривога і екстаз».

Окрім цього, ми би хотіли звернути увагу на поняття «supplice», перекладене як «муки». Це поняття є також доволі багатим на конотації: передусім йдеться про досвід розіп'ятого Христа в момент його крику «у eli lama sabachtani» («нащо Мене Ти покинув?»). Батай звертається до цього біблійного сюжету з метою ілюструвати внугрішній досвід, але не самого Христа, а християнина, що сповнюється стражданням Спасителя, тілесним i духовним. Найвищої сили таке переживання набуває в той момент, коли сам Христос втрачає Бога, віру, трансцендентне. Це найвищий ступінь муки, саме його має пережити святий чи свята. Саме його, на погляд Батая, переживає китаєць із фотографій Бореля під час страти «тисяча шматочків». «У духовних вправах Ігнатія Лойоли та роздумах Іоанна від Хреста медитація на хресті - це засіб, за допомогою якого Я розчиняється у внугрішньому досвіді. У “Внутрішньому досвіді" ту саму функцію виконує серія фотографій - “бентежних картинок” (images bouleversantes) - тортур китайського царевбивці, які Батай довго тримав у себе» [Poppenberg 2016: 143-144]. Отже, процес страчення, супроводжуваний тілесним катуванням аж до екзальтованого стану жертви - ще один сильний приклад внутрішнього досвіду, наведений Батаєм. Для того, щоб урахувати всі ці аспекти, ми і використовуємо поняття «муки», адже для українського читача воно має релігійну конотацію пов'язаності тілесних та духовних страждань, предмет яких - зневіра та ії подолання. От тільки для Батая зневіра і $\epsilon$ крайньою межею такого досвіду.
Деякі важливі поняття тексту Батая ми залишили латинськими: так, «communication» перекладене як «комунікація», а «discourse» - як «дискурс». Під поняттям «дискурс» Батай розуміє сутність європейського філософування, проти якого він хотів би повстати в текстах робіт із «Summa Atheologica», i у «Внутрішньому досвіді» зокрема: «Знаю, що достатньо розбити дискурс в собі, і ось він екстаз, від якого лише дискурс відділяє мене, екстаз, який зраджує дискурсивна думка, пропонуючи його як вихід або як відсутність виходу. Безсилля волає в мені (я пам'ятаю), протяжним, тривожним внутрішнім криком: пізнати, нічого не знати». «Комунікація»напрочуд важливий термін, він руйнує концепцію внутрішнього досвіду як внутрішнього, оскільки життя не обмежується цим невблаганним внутрішнім потоком, що розколює мовучерез неоднорідність слів: «Більше немає ані суб'єкта, ані об’єкта, та є “зяючий пролом” між ними, і в цьому проломі суб 'єкт і об'єкт розчинені, є перехід, комунікація, але не від одного до іншого: і один, і інший втратили окреме існування. Питання суб'єкта, його воля знати скасовані: суб' єкта там уже немає, його запитання не мають більше ані сенсу, ані засадничого принципу».

Низка понять, що є також глибоко вкоріненими в філософський дискурс: «esprit» (дух), «entendement» (розуміння), «intelligence» (розум), «savoir» (знання), «connaissance» (пізнання). Батай використовує їх, але в його тексті вкрай важно знайти послідовність та методичність застосування. 3 огляду на це, нашим завданням було надати вже сталий, домовлений переклад цих понять, спираючись на відповідні статті у «Європейському словнику філософій». Зокрема, в статті «Entendement» читаємо про встановлення традиції використання цього терміну як французького аналогу латинського «intellectus»: «Декарт, ототожнюючи cogitatio не лише 3 entendement, а й воднораз із mens, animus, intellectus i ratio ... вдається до загальнопоширеного розрізнення між «сприйняттям entendement» і «дією волі»... Відтоді entendement переважно пов'язується 3 логікою, набуває дискурсивності своїх процедур, розрізняє істинне та хибне» [Туар 2011: 74-75]. Батай спирається на картезіанське «розуміння» з метою відхилитися від нього як основи дискурсивного судження: «Дія запроваджує пізнане (вироблене), потім розуміння, пов'язане з нею, співвідносить один за одним не-вироблені, непізнані елементи 3 пізнаними. Але бажання, поезія, сміх невпинно підштовхують життя зісковзнути в протилежному напрямку, рухаючись від пізнаного до непізнаного. Існування наприкінці виявляє сліпу пляму розуміння і одразу повністю в неї занурюється».

Окремо варто виокремити поняттєву сполуку понять «ірse» та «ipseit?». Якщо перше ми залишили без перекладу, то друге переклали як «самість»,спираючись на уже наявну традицію такого перекладу 
[Васильченко 2011: 429]. У згадуваній нами рецензії на «Внугрішній досвід» Сартр наводить думку, що Батай запозичує цей термін із перекладу Анрі Корбена німецького «Selbstheit» Гайдегера, що відображає повернення до себе як основу проекту, як рефлексивний стосунок, конституйований у переживанні [Sartre 1975: 202]. Сам Батай використовує «самість» лише як похідне від «ірsе», яке він зіставляє з «је» («я») у контексті гегельянської діалектики пана і раба: «Моє “я” втілює покірну ницість - не тією мірою, якою воно є воно абсурдним, непізнаваним ipse, але через двозначність між одиничністю цього ірse та універсальністю розуму». Але його мета зафіксувати перетворення «ірse» на «самість», що розчиняється в екстатичній комунікації досвіду. Як зазначає дослідник П. Бюргер, тривога перетворюється на радісний досвід екстазу саме в момент, коли «я» готове себе втратити і обернутися на «ірse» [Bürger 2002: 35].

Зрештою, завдання вписати український переклад Батая в сучасну традицію українських перекладів західних філософських текстів варто визнати утопічним. Адже сама особистість Батая опирається будь-якій філософській традиції, його письмо - антидискурсивне і поетизоване. Перекладачу важко розпізнати терміни, бо, хоча Батай не прагне мислити термінологічно: він відштовхується від філософської термінології, але прагне здолати ії. Поняття для нього - частина дискурсу, який він піддає сумніву як умову можливості досвіду. У власному тексті Батай неодноразово зізнається у помилках, недосконалості виконання свого задуму, і зрештою у неможливості задумів як таких. Відповідно, і перекладачу, і читачу «Внутрішнього досвіду» варто змиритися із стилістикою розтрати слів, термінів, конотацій у цій праці. Це жертвопринесення було здійснене Батаєм неодноразово, і не безцільно: адже нове покоління філософів (серед яких Ж. Бодріяр Ж. Дерріда, Ю. Крістева та М. Фуко) знайшло у ньому джерело для натхнення.

«Муки» Батая, його публічне самострачення задля екстатичного переживання, яке він мав надію описати і дослідити, набуло значення середньовічної страти посеред площі - низка французьких інтелектуалівсучасників (групи сюрреалістів на чолі з А. Бретоном, Г. Марселя і, насамперед, Ж.-П. Сартра) зібралася довкола, щоб повирячуватись, поглузувати, поспівстраждати. Та, напевно, це було батаєвським завданням - комунікація досвіду, комунікація як найвища цінність, нехай задля неї доведеться пережити справжні муки внутрішнього досвіду.

Список використаної літератури

Васильченко, А. (2011) Самість. Пер. В. Артюха, в: Свропейський словник філософій: Лексикон неперекладностей. T. 2. Пер. $з$ фр. Хоми О., за ред. Панича О. Київ: Дух і літера, сс. 429-434.

Туар, Д. (2011) Entendement. Пер. О. Хоми, в: Європейський словник філософій: Лексикон неперекладностей. Т. 2. Пер. з фр. Хоми О., за ред. Панича О. Київ: Дух і літера, сс. 73-78.

Bataille, G. (1973) L'Expérience intérieure, in: Bataille, G. Oeuvres complètes. Tome V. La Somme Athéologique I, Paris, Gallimard, pp. 7-189.

Bataille, G. (1976) Notice Autobiographique, in: Bataille, G. Oeuvres complètes VII, Editions Gallimard, pp. 459-462.

Boldt, L. A. (1988) Translator's Introduction, in : Bataille, G. Inner Experience, Translated and with an Introduction by Leslie Anne Boldt State University of New York Press pp. ix-xxiv.

Bürger, P. (2002) The Thinking of the Master. Bataille between Hegel and Surrealism. Northwestern University Press.

Janet, P. (1926) De l'angoisse à l'extase. T. I. Études sur les croyances et les sentiments. Retrieved from https://psychaanalyse.com/pdf/ de 1 angoisse a 1 extase pierre janet Janet 1 pt 1 ch 1 2.pdf

Kendall, S. (2014) Translator's Introduction: A Debauchery of Thought, in: Bataille, G. Inner Experience; translated and with an introduction by Stuart Kendall. State University of New York.

Noys, B. (2000) Georges Bataille: a critical introduction. Pluto Press, London. Poppenberg, G. (2016) Inner Experience, in: Georges Bataille. Key Concepts. Hewson, Mark and Coelen, Marcus, editors. Routledge.

Rousseau, G. (2015), Bataille absurde: de l'angoisse au rire. Retrieved from http://www.implications-philosophiques.org/actualite/une/bataille-absurdede-langoisse-au-rire/

Sartre, J.-P. (1975) Un nouveau mystique, in: Critiques littiraires (Situations. I). Paris: Gallimard (Idees), pp. 174-229.

Евгения Буцыкина

КОММЕНТАРИЙК УКРАИНСКОМУ ПЕРЕВОДУ ПРОИЗВЕДЕНИЯ

\section{ЖОРЖА БАТАЯ «ВНУТРЕННИЙ ОПЫТ»}

Комментарий посвящен проблематике перевода на украинский язык произведения «Внутренний опыт» известного франиузского интеллектуала ХХ века Жоржа Батая. В работе обозначена короткая история публикачий и расширений произведения, что составляет для переводчика определенную сложность и начальное условие для неполного перевода произведения, которое не было опубликовано в полном объеме при жизни автора. Также в тексте осуществлен анализ ключевых философских терминов, перевод которых сопровождался проблематичностью: в частности, это такие понятия, как «angoisse» 
(тревога), «sиррlice» (муки), «соттипісаtion» (коммуникация), discourse (дискурс), «еsprit»(дуx), «entendement» (понимание), «intelligence» (ум), "savoir» (знание), «connaissance» (познание), «ірsе» (не переведено) и «ірлеité» (самость). Антидискурсивность и поетизованность отмечены как ключевые характеристики письма Батая, что также способствовало усложнению такой задачи, как перевод «Внутреннего опьта».

Ключевые слова: Батай, дискурс, опыт, коммуникация, муки, самость, тревога.

\section{Yevheniia Butsykina}

\section{COMMENTARYONTHE UKRAINIANTRANSLATIONOF"INNER}

\section{EXPERIENCE"BYGEORGESBATAILLE}

The commentary is devoted to the Ukrainian translation of "Inner Experience» work by Georges Bataille, the famous French intellectual of the twentieth century. The paper outlines a short history of publications and extensions of "Inner Experience», which is a certain difficulty for the translator and the initial condition for incomplete translation of the work, which was not published in full while its author was alive. The paper is devoted to analysis of the key philosophical terms, the translation of which was problematic: in particular, such concepts as "angoisse» (anxiety), "supplice» (torment), "communication» (communication), "discourse»(discourse), "esprit» (mind),» entendement (understanding), «intelligence» (intelligence), «savoir» (knowledge), «connaissance» (knowledge), «ipse» (not translated) and «ipseité» (self). The concept of "anguish» provides an opportunity to fit Bataille into the existing existentialist-phenomenological tradition (understanding "anguish» as the "anxiety», a key concept in Kierkegaard, Heidegger and Sartre works). The concept of supplice is also rich in connotations: it is primarily about the experience of the crucified Christ at the moment of his cry «in eli lama sabachtani» ("why have you forsaken me?»). Bataille refers to this biblical story in order to illustrate the inner experience, but not of Christ himself, but of the Christian, who is filled with the Savior's suffering, both physical and spiritual.

Emphasis was placed on anti-discoursiveness and poeticism as key characteristics of Bataille's writing, which also contributed to the complication of such a task as the translation of the work «Inner Experience». It is stated that both the translator and the reader of «Inner Experience» should come to terms with the style of wasting words, terms, and connotations in this work. This sacrifice was performed by Bataille repeatedly, and not aimlessly: after all, a new generation of philosophers (among whom J. Baudrillard, J. Derrida,
J. Kristeva and M. Foucault) found in him a source of inspiration.

Keywords: Bataille, discourse, experience, communication, torment, self, anguish.

\section{References}

Vasilchenko, A. (2011) Samist [Selfhood]. Per. V. Artjuha, in: Yevropejskij slovnik filosofij: Leksikon neperekladnostej. T. 2. Per. z fr. HomyO., za red. Panicha O. Kyiv, Dukh i litera, pp. 429-434.

Toir, D. (2011) Entendement. Per. O. Homy, in: Yevropejskij slovnik filosofij: Leksikon neperekladnostej. T. 2. Per. z fr. Homy O., za red. Panicha O. Kyiv, Dukh i litera, pp. 73-78.

Bataille, G. (1973) L'Expérience intérieure, in: Bataille, G. Oeuvres complètes. T. V. La Somme Athéologique I, Paris, Gallimard, pp. 7-189.

Bataille, G. (1976) Notice Autobiographique, in: Bataille, G. Oeuvres complètes. T. VII, Editions Gallimard, pp. 459-462.

Boldt, L. A. (1988) Translator's Introduction, in: Bataille, G. Inner Experience, transl. and with an Introduction by Leslie A. B. State University of New York Press, pp. ix-xxiv.

Bürger, P. (2002) The Thinking of the Master, in: Bataille between Hegel and Surrealism. Northwestern University Press.

Janet, P. (1926) De l'angoisse à l'extase. Tome I. Études sur les croyances et les sentiments. Retrieved from https://psychaanalyse.com/pdf/ de_1_angoisse_a_1_extase_pierre_janet_Janet_1_pt1_ch_1_2.pdf

Kendall, S. (2014) Translator's Introduction: A Debauchery of Thought, in: Bataille, G. Inner Experience; translated and with an introduction by Stuart Kendall. State University of New York.

Noys, B. (2000) Georges Bataille: a critical introduction. Pluto Press, London.

Poppenberg, G. (2016) Inner Experience, in: Georges Bataille. Key Concepts. Hewson, Mark and Coelen, Marcus, editors. Routledge.

Rousseau, G. (2015), Bataille absurde: de l'angoisse au rire. Retrieved from $\mathrm{http} / /$ www.implications-philosophiques.org/actualite/une/bataille-absurdede-langoisse-au-rire/

Sartre, J.-P. (1975) Un nouveau mystique, in: Critiques littiraires (Situations. I). Paris, Gallimard (Idees), pp. 174-229.

Стаття надійшла до редакиії 3.05.2021 Стаття прийнята 18.06.2021 